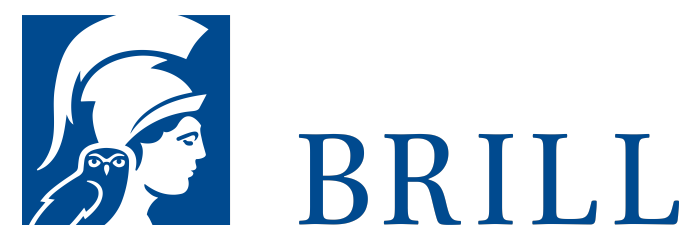

\title{
Das Wissen von der ganzen Welt
}

Globale Geographien und räumliche Ordnungen Afrikas und Europas 1790-1870

Author: Iris Schröder

Die Globalisierung hat eine Geschichte, aber sie hat auch eine Geographie.

Die Autorin beschreibt die Neuerfindung des Raumes im frühen 19. Jahrhundert. Es ist eine Geschichte der späten europäischen Gelehrtenrepublik in Paris, Berlin und London. Mit Vorliebe widmeten sich diese Gelehrten der Erforschung Afrikas, die von ihnen entsandten Reisenden begaben sich ins abenteuerliche Ungewisse. Die Geographie Europas führte dagegen ein Schattendasein: sie blieb mit einer älteren politischen Geographie verknüpft.

Die Studie behandelt das Spannungsfeld von Raum und Geschichte und zeigt, wie sich seit 1800 im westlichen Europa eine wenig bekannte Verräumlichung des Wahrnehmungshorizonts vollzogen hat. Die Autorin fragt damit nach der Genese, der Vielfalt und Situiertheit vermeintlich überzeitlicher universeller Raumvorstellungen.

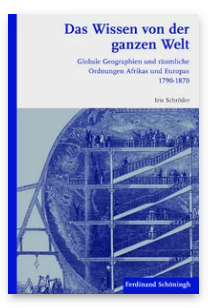

Pages: 411

Seiten, $12 \mathrm{~s} / \mathrm{w}$ und 12 farb. Abb.

Language:

German

Subjects: Early

Modern History, History

Publisher: Brill |

Schöningh

Hardback

Publication date:

20 Jul 2011

ISBN: 978-3-

506-77158-2

List price

USD $\$ 75.00$ 
Biographical Note

Dr. Iris Schröder arbeitet am SFB 640 »Repräsentationen sozialer Ordnungen im Wandel « und lehrt an der Berliner HumboldtUniversität.

For more information see brill.com

Order information: Order online at brill.com +44 330 333 0049 | customerservices@brill.com Submission information: brill.com/authors

Titles published by Brill | Fink, Brill | mentis or Brill | Schöningh: +49(o)71 5413279216 | brill@brocom.de 